\title{
Oligodendrocyte Cell Adhesion Molecules Are Related to Neural Cell Adhesion Molecule (N-CAM)
}

\author{
Shama Bhat and Donald H. Silberberg \\ Department of Neurology, University of Pennsylvania School of Medicine, Philadelphia, Pennsylvania 19104
}

The glycoproteins responsible for calcium-dependent oligodendrocyte aggregation were purified and characterized. Using detergent extraction, lentil-lectin-Sepharose $4 B$ affinity chromatography, and preparative gel electrophoresis, 3 proteins were purified to apparent homogeneity, with relative $M_{r} s$ of 120,000 , 140,000 , and 180,000 . The aggregation assay showed that all 3 proteins had the ability to block antibody-mediated inhibition of oligodendrocyte aggregation. The 120,000 protein was the most active of the three. Antisera were raised in rabbits to these 3 individual proteins. Western blot analyses showed that all three antisera recognized $120,000,140,000$, and 180,000 proteins, which indicated that the proteins were related. Westernblot analyses of cultured oligodendrocytes and purified rat myelin showed only the 120,000 protein. Immunoprecipitation of iodinated membrane proteins of cultured oligodendrocytes also indicated the presence of only the $120,000 M_{\mathrm{r}}$ protein. Deglycosylation of the 120,000 protein by $N$-glycanase resulted in a 110,000 protein. The immunoblot pattern suggested some similarities between oligodendrocyte adhesion molecules and the neural cell adhesion molecule (N-CAM). Therefore, the $\mathbf{1 2 0 , 0 0 0}$, 140,000 , and $180,000 M_{\mathrm{r}}$ proteins were compared to N-CAM by Western-blot analysis, immunofluorescence staining, and by immunoprecipitation. The results suggest that oligodendrocytes contain a 120,000 membrane glycoprotein that is related to N-CAM.

The glycoproteins responsible for adhesion between neurons have been studied independently under the names N-CAM (neural cell adhesion molecules) (Edelman et al., 1983; Rutishauser, 1983), D2-CAM (Jorgensen et al., 1980), and BSP-2 (Goridis et al., 1983; Hirn et al., 1983). It has becn suggestcd that neuronal-glial adhesion involves another type of adhesion molecule-NgCAM (Edelman, 1984; Grumet et al., 1983, 1984). It was reported earlier that glia do not express N-CAM/D2CAM in vitro (Grumet et al., 1983, 1984; Hirn et al., 1981). However, recently, Noble et al. (1985) and Keilhauer et al. (1985) have shown that glial cells express N-CAM/D2-CAM in vitro. We have reported that oligodendrocytes $(\mathrm{OL})$ have cell adhesion molecules, which are responsible for OL aggregation (Bhat and Silberberg, 1985). Here we report on the purification and characterization of an oligodendrocyte cell adhesion molecule (OL-CAM), which is closely related to one of the N-CAM family of glycoproteins.

Received Feb. 6, 1986; revised Apr. 15, 1986; accepted Apr. 17, 1986

We are grateful to Dr. David Pleasure for helpful suggestions regarding the manuscript, to Ms. Michele Richardson for technical assistance, to Dr. U. Rutishauser (N-CAM) and Dr. M. Schachner ("01" and "04") for the kind gifts of antibodies, and to Ms. Lori Buell for typing the manuscript. We also thank Ms. Lois Murphy for helping in the iodination experiments. This work was supported by grants from the National Multiple Sclerosis Society, the National Institutes of Health (NS11037), and the Frank Strick Foundation.

Correspondence should be addressed to Shama Bhat, Ph.D., Department of Neurology, University of Pennsylvania School of Medicine, 3400 Spruce Street, Philadelphia, PA 19104.

Copyright (C) 1986 Society for Neuroscience $0270-6474 / 86 / 113348-07 \$ 02.00 / 0$

\section{Materials and Methods}

\section{OL aggregation assay}

The immunological assay of $O L$ aggregation was as described previously (Bhat and Silberberg, 1985). OL $\left(2 \times 10^{5}\right.$ cells $)$ in $10 \mu \mathrm{l}$ PBS were added to tubes that contained $40 \mu$ l of cold PBS, plus a solution of antibody or a mixture of antibody and the protein fractions to be assayed, which had previously been incubatcd together for $20 \mathrm{~min}$ at room temperature. After $30 \mathrm{~min}$ at $4^{\circ} \mathrm{C}$, the cells were diluted to $100 \mu \mathrm{l}$ with cold Dulbecco's modified Eagle's medium (DME) containing $20 \mu \mathrm{g} / \mathrm{ml}$ DNAse, $1 \%$ fetal bovine serum, and $10 \mathrm{mM}$ HEPES, mixed vigorously, placed in a capped tube, and rotated in a shaker at $100 \mathrm{rpm}$ at $37^{\circ} \mathrm{C}$. After 0 and $30 \mathrm{~min}$ of incubation, aliquots were removed and unaggregated single cells were counted, using a hemocytometer (Bhat and Silberberg, 1985).

\section{Preparation of membrane extracts of rat brain and cultured $O L$}

Rat brains or cultured OL were homogenized in PBS containing 0.3 mM phenylmethyl sulfonyl fluoride (PMSF; Sigma) and centrifuged at $1000 \times g$ for $5 \mathrm{~min}$ to remove the nuclei and cell debris. The supernatant was spun at $15,000 \times g$ for $20 \mathrm{~min}$. The pellet was suspended in PBS containing $0.3 \mathrm{~mm}$ PMSF, $0.5 \%$ NP40 (NP40 buffer), and incubated overnight at $4^{\circ} \mathrm{C}$. The suspension was centrifuged at $100,000 \times g$ for $90 \mathrm{~min}$. This supernatant is NP40 extract.

\section{Purification of $O L-C A M$}

Lentil lectin Sepharose 4B (Sigma) was equilibrated with NP40 buffer and the gel $(50 \mathrm{ml})$ was mixed with $50 \mathrm{ml}$ of NP40 extract for $2 \mathrm{hr}$ at $4^{\circ} \mathrm{C}$. The supernatant was removed and the gel was packed in a column. The column was washed with $500 \mathrm{ml} \mathrm{NP40}$ buffer and eluted with 0.5 м $\alpha$-methylmannoside (Sigma) in NP40 buffer. The eluted material was dialyzed against PBS and concentrated by Diaflo-concentrating system (Amicon) using 50,000 $M_{\mathrm{r}}$ cut-off membranes. The concentrated glycoproteins were then precipitated by acetone. The concentrated material was incuhated with 6 vol of acetone at $-20^{\circ} \mathrm{C}$ for $16 \mathrm{hr}$. After centrifugation at $8000 \times g$ for $30 \mathrm{~min}$, the pellet was dissolved in sample buffer for preparative gel electrophoresis. For aggregation assay, the precipitates were washed 2 times with PBS to remove traces of NP40 and SDS. For preparative SDS-PAGE, 3-mm-thick, $7.5 \%$ separating and $5 \%$ stacking gels were used (Laemmli, 1970). After electrophoresis $(10 \mathrm{~mA}, 16 \mathrm{hr})$, the gel was cut into thin $(3 \mathrm{~mm})$ slices in the region of 95,000-200,000 $M_{\mathrm{r}}$, minced, and eluted with $3 \mathrm{ml}$ of NP40 buffer for $3 \mathrm{~d}$ at $4^{\circ} \mathrm{C}$. The eluted proteins were tested for activity by immunoblot (see below) and aggregation assay. The purity of the fractions was checked by SDS-PAGE. If more than 1 protein band was observed, the eluted protein was re-electrophoresed using $1.5 \mathrm{~mm}$ SDS-PAGE, and re-eluted as above. The proteins exhibiting neutralizing activity in the above aggregation assay were the oligodendrocyte cell adhesion molecules (OLCAM).

\section{Antibody preparation}

Production of antibodies to OL-conditioned medium was as described (Bhat and Silberberg, 1985). In order to raise antibodies to individual polypeptides, the $120,000,140,000$, and 180,000 polypeptides were eluted from the preparative gels and precipitated by acetone. About 50 $\mu \mathrm{g}$ of acetone-precipitated proteins were suspended in $250 \mu \mathrm{l} \mathrm{PBS}$, mixed with $250 \mu$ l Freund's complete adjuvant, and injected into rabbits 3 times at 2 week intervals, and boosted with $100 \mu \mathrm{g}$ protein in PBS alone. 


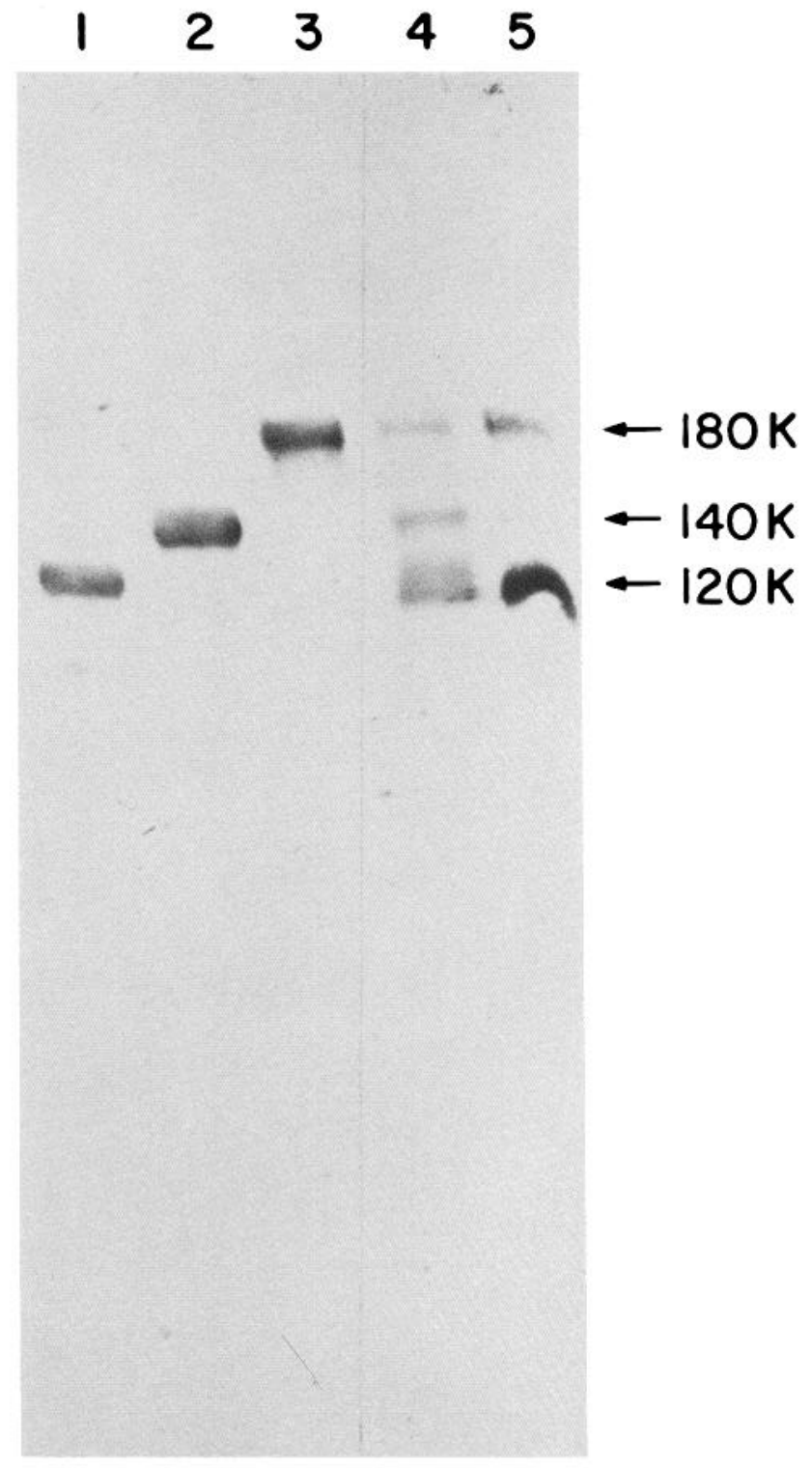

Figure 1. Western-blot analysis of OL-CAM. Lane 1, 120,000 (5 $\mu \mathrm{g})$; lane 2, 140,000 (5 $\mu \mathrm{g})$; lane 3, 180,000 (5 $\mu \mathrm{g})$; lane 4, lentil lectin elute $(50 \mu \mathrm{g})$; lane 5, NP40 extract $(100 \mu \mathrm{g})$. Proteins were resolved by SDSPAGE and then elecrophoretically transferred to nitrocellulose paper. Proteins were immunologically stained using anti-conditioned medium (1:5000 dilution) and HRP-conjugated IgG (HRP-IgG) (1:3000 dilution).

One week after the booster injections, the rabbits were bled and sera were separated. The preparation of immunoglobulins and Fab fragments was as previously described (Bhat and Silberberg, 1985).

\section{Cell culture and $O L$ isolation}

Preparation and maintenance of both primary mixed cultures of fetal rat brain and rat OL were as described previously (Bhat and Silberberg, 1985).

\section{SDS-PAGE and immunoblot}

SDS-PAGE (Laemmli, 1970) was carried out with 1.5-mm-thick, 7.5\% separating and 5\% stacking gels. After electrophoresis, the proteins were electrophoretically transferred to nitrocellulose paper (Bio-rad) (Towbin et al., 1979). Immunostaining was performed using appropriate antisera and an immunoblot kit (Bio-rad) as suggested by the supplier.

\begin{tabular}{|c|c|c|c|c|c|}
\hline Fraction & $\begin{array}{l}\text { Protein } \\
\text { (mg) }\end{array}$ & $\begin{array}{l}\text { Total } \\
\text { activity } \\
\text { (U) }\end{array}$ & $\begin{array}{l}\text { Specific } \\
\text { activity } \\
\text { (U/mg) }\end{array}$ & $\begin{array}{l}\text { Yield } \\
(\%)\end{array}$ & $\begin{array}{l}\text { Puri- } \\
\text { fication } \\
(n \text {-fold })\end{array}$ \\
\hline NP40 extract & 750 & 12,750 & 17 & 100 & 1 \\
\hline Lentil lectin elute & 45 & 10,710 & 238 & 84 & 14 \\
\hline 120,000 & 0.24 & 1380 & 5750 & & \\
\hline 140,000 & 0.36 & 785 & 2175 & & \\
\hline 180,000 & 0.48 & 990 & 2063 & & \\
\hline \multicolumn{6}{|l|}{$120,000,140,000$, and } \\
\hline 180,000 combined & 1.08 & 3155 & 2921 & 25 & 172 \\
\hline
\end{tabular}

The amount of OL-CAM activity in a sample was estimated by its ability to neutralize the aggregation-blocking ability of Fab, prepared from the sera of rabbits immunized with OL-conditioned medium. One unit of OL-CAM activity is defined as the amount of OL-CAM required to reduce the aggregation by $25 \%$. OL-CAM was purified from 3-week-old rat brain membranes by NP40 extraction, followed by lentil-lectin affinity chromatography and preparative SDS-PAGE (see Materials and Methods for details).

\section{Iodination and immunoprecipitation}

Iodination of the NP40-extracted proteins $(250 \mu \mathrm{g})$ was performed using $25 \mu \mathrm{Ci}{ }^{125}$ I Bolton-Hunter reagent (ICN Biochemicals) as described (Bolton and Hunter, 1973) Immunoprecipitation was as described by Dobberstein et al. (1979). After immunoprecipitation, the slurry was boiled for $10 \mathrm{~min}$ with sample buffer. After electrophoresis, the gel was autoradiographed using Kodak X-O-Mat film.

\section{Myelin}

Isolation of myelin fractions from adult rat brains was as described by Norton and Poduslo (1973), using sucrose density gradient centrifugation.

\section{$\mathrm{N}$-Glycanase cleavage of $O L-C A M$}

Membranes (100 $\mu \mathrm{g}$ protein) from enriched cultures of OL were solubilized with $0.5 \%$ SDS and $0.1 \mathrm{~m} \beta$-mercaptoethanol and boiled for 3 min. The sample was diluted with sodium phosphate buffer $(\mathrm{pH} 8.6)$, EDTA and NP40. $N$-Glycanase (peptide: $N$-glycosidase F) (Genzyme) was then added and the reaction mixture incubated overnight at $30^{\circ} \mathrm{C}$. The final concentrations were $0.17 \%$ SDS, $0.02 \mathrm{M} \beta$-mercaptoethanol, $0.2 \mathrm{M}$ sodium phosphate, $5 \mathrm{~mm}$ EDTA, $1.25 \% \mathrm{NP} 40$, and $10 \mathrm{U} / \mathrm{ml}$ $\mathrm{N}$-glycanase, in a total volume of $30 \mu \mathrm{l}$. Controls were treated similarly, except for the $\mathrm{N}$-glycanase. The reaction was terminated by boiling for $3 \mathrm{~min}$, and analyzed by Western blot.

Protein estimation was done by the method of Lowry et al. (1951).

\section{Results}

\section{Purification of $O L-C A M$}

Earlier, we reported that rat OL have cell adhesion molecules (Bhat and Silberberg, 1985). Antibodies raised to OL-conditioned medium inhibited the aggregation of $O L$, which was used to quantitate the OL-CAM. Immunoblot analysis of OL-conditioned medium showed many protein bands. When OL membranes were analyzed by immunoblot, about 6 bands were observed (data not shown) (later, it was found that most of these bands were serum components). However, the NP40 extract of 3-week-old rat brain membranes showed only 3 bands, with apparent $M_{\mathrm{r}} \mathrm{s}$ of $180,000,140,000$, and 120,000 . Lentil lectin Sepharose 4B was used to purify the molecules responsible for OL aggregation. As is shown in Table 1, the molecules bound to lentil lectin had OL-CAM activity. Analysis with SDS-PAGE showed many bands, but Western-blot analysis showed only 3 bands. The aggregation assay showed that, at this stage, there was a 14-fold purification of OL-CAM activity. The lentil-lectin-bound glycoproteins were used to purify OL-CAM by means 


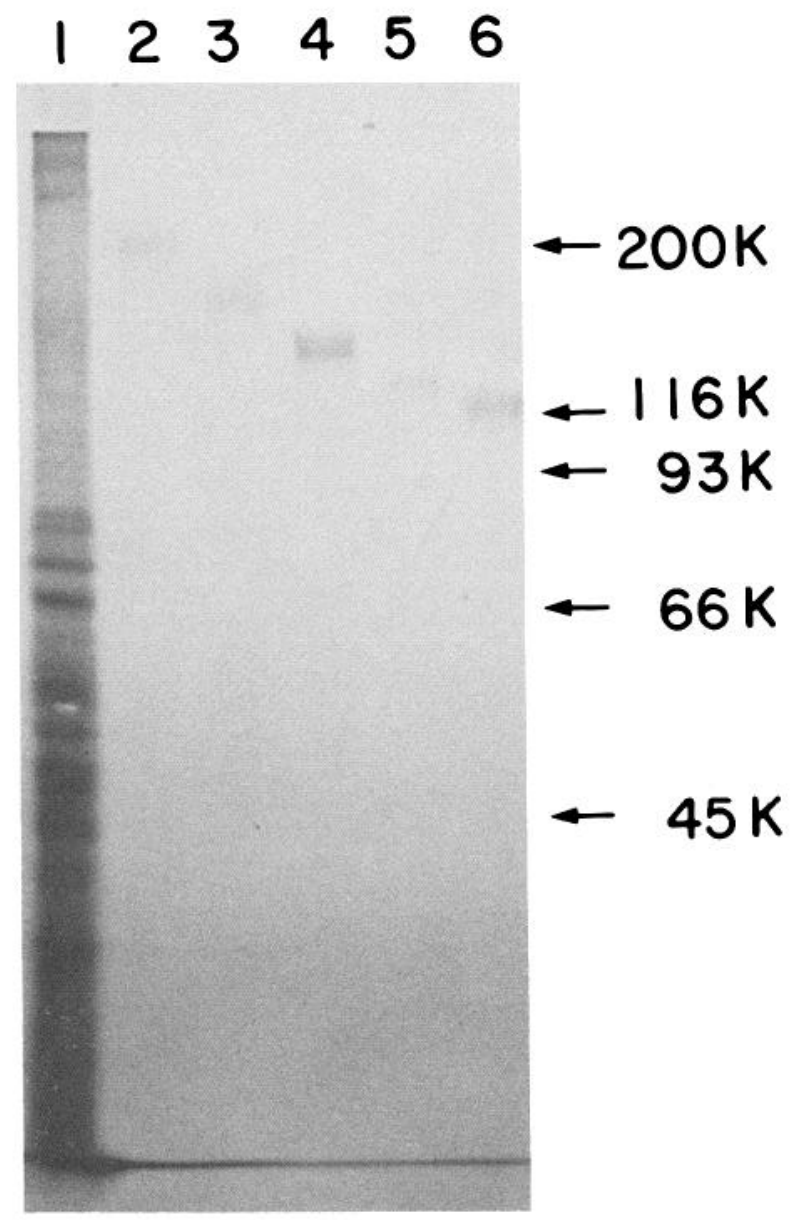

Figure 2. SDS-PAGE of OL-CAM. Lane 1, Lentil lectin elute (100 $\mu \mathrm{g})$; lane 2, 180,000 (15 $\mu \mathrm{g})$; lane 4, 140,000 $(20 \mu \mathrm{g})$; lane 6, 120,000 $(20 \mu \mathrm{g})$; lanes 3 and 5 , fractionated proteins $(15 \mu \mathrm{g})$ that did not have OL-CAM activity. Proteins were resolved by $7.5 \%$ separating gel and staining with Coomassie blue.

of preparative SDS-PAGE. The eluted proteins were analyzed by aggregation assay (Table 1) and by Western blot (Fig. 1). Of the 10 fractions in the region of $95,000-200,000$, only 3 had OL-CAM activity, with apparent $M_{\mathrm{r}} \mathrm{s}$ of $120,000,140,000$, and 180,000 . On SDS-PAGE analysis, these 3 fractions showed only 1 band each with Coomassie blue or silver stain (Fig. 2). The aggregation assay showed about 172-fold purification. It is of interest to note that the 120,000 protein had the highest OLCAM activity, as compared to those of 140,000 and 180,000 .

\section{Immunoblot and immunoprecipitation analysis of rat brain} membranes, myelin, and membranes from cultured $O L$ using anti-OL-CAM

Membranes from rat brain and cultured OL (about $90 \%$ enriched) were solubilized by $1.0 \% \mathrm{NP} 40$ and analyzed by immunoblot (Fig. 3) and SDS-PAGE after ${ }^{125}$ I iodination and immunoprecipitation (Fig. 4). As is shown in Figure 3, antibodies raised to individual bands reacted with all 3 proteins, which is comparable with anti-OL-conditioned medium and anti-N-CAM (see below). However, cultured OL had only 1 band, with an apparent $M_{\mathrm{r}}$ of 120,000 . Highly purified rat myelin had only a 120,000 band (Fig. 3).

\section{$\mathrm{N}$-Glycanase cleavage of $O L-C A M$}

Membranes from enriched cultures of OL were treated with $\mathrm{N}$-glycanase. $\mathrm{N}$-Glycanase hydrolyzes $\mathrm{N}$-asparagine-linked ol-

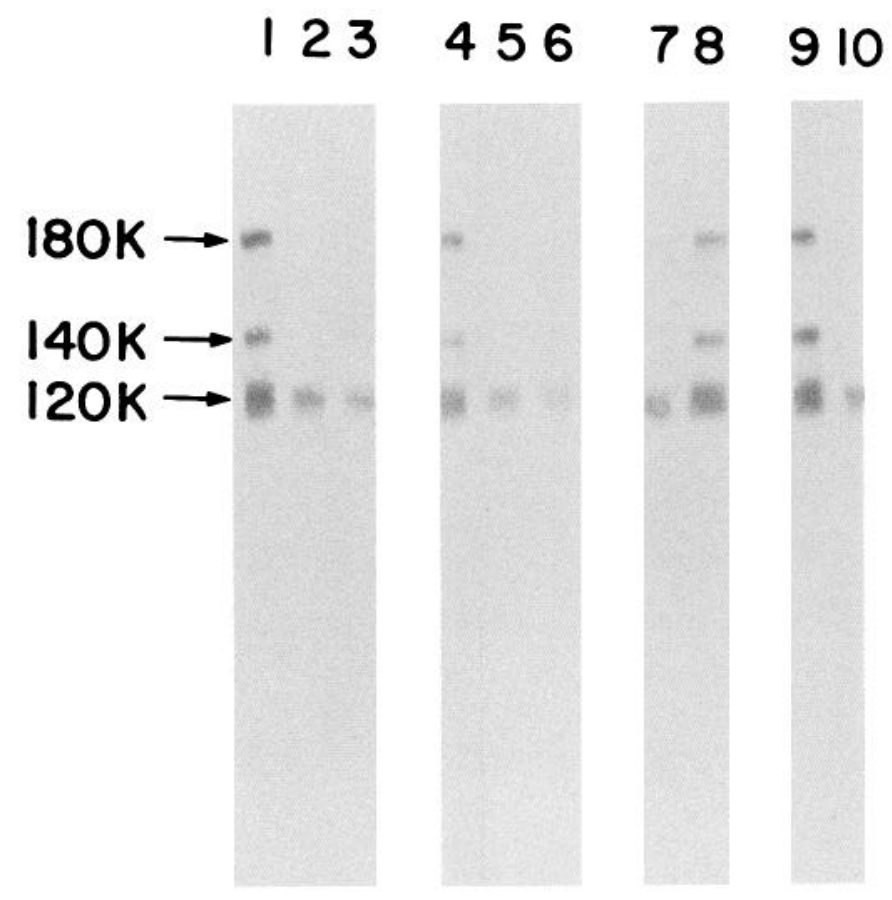

Figure 3. Western-blot analysis of rat brain, myelin and cultured OL membranes using anti-N-CAM and anti-OL-CAM sera. NP40 extract (lanes $1,4,8,9 ; 100 \mu \mathrm{g}$ ), myelin (lanes 3,$6 ; 100 \mu \mathrm{g}$ ) and OL membranes (lanes $2,5,7,10 ; 50 \mu \mathrm{g}$ ) were resolved by SDS-PAGE. The proteins were then electrophoretically transferred to nitrocellulose paper, followed by immunostaining using anti-120,000 (1:2000; lanes 1-3) antiN-CAM-IgG $(0.05 \mathrm{mg} / \mathrm{ml}$; lanes 4-6), anti-180,000 (1:2000; lanes 7 , $8)$, and anti-140,000 (1:2000; lanes 9, 10).

igosaccharides from glycoproteins, yielding free oligosaccharide and a protein containing aspartic acid at the glycosylation site (Elder and Alexander, 1982). As is shown in Figure 5, treatment with $N$-glycanase gave a protein with an apparent molecular weight of 110,000 .

\section{$N-C A M$ and $O L-C A M$ are identical or closely related proteins} In the adult rat or mouse brain, the N-CAM reportedly has 3 separate but related proteins, with apparent $M_{\mathrm{r}} \mathrm{s}$ of 120,000 , 140,000 , and 180,000 (Edelman and Choung, 1982; Hirn et al., 1981; Rasmussen et al., 1982). Therefore, we wanted to compare N-CAM with OL-CAM by using antibodies raised to purified N-CAMs. As is shown in Figures 6 and 3, both anti-N-CAM and anti-conditioned medium stained identical bands in both the NP40 extract and purified proteins. Immunoprecipitation using anti-N-CAM and anti-conditioned medium showed identical bands (Fig. 4). Western-blot analysis of cultured OL membrane proteins with anti-N-CAM showed only a 120,000 protein (Fig. 3).

\section{Immunofluorescence analysis of cultured $O L$ using} anti-N-CAM and anti-OL-CAM

Four days after isolation and culturing, OL were stained by various antisera (Fig. 7 and Table 2). OL were identified using antibodies to cell-specific surface markers such as "04," "01," and galactosyl-cerebroside (GalC). Anti-GalC (Raff et al., 1978) and "01" (Singh and Pfeiffer, 1985; Sommer and Schachner, 1981) antibodies stain well-differentiated OL, whereas " 04 " stains developing OL (Sommer and Schachner, 1982). In some experiments, we used monoclonal anti-GalC, while in others the monoclonal " 01 " antibody was used. In both cases, the results were similar. We report here only the experiments using 


\section{$\begin{array}{llllllll}1 & 2 & 3 & 4 & 5 & 6 & 7 & 8\end{array}$}

\section{$180 \mathrm{~K} \rightarrow$}

$140 \mathrm{~K} \rightarrow$

$120 \mathrm{~K} \rightarrow$
Figure 4. Immunoprecipitation of OL-CAM from rat brain and cultured OL membranes. NP40 extracts of rat brain (lanes $2,4,6,8$ ) and OL (lanes $1,3,5,7)$ were radio-iodinated. ${ }^{125}$ I NP40 extract proteins $(30 \mu \mathrm{g})$ were immunoprecipitated with anti120,000 (4 $\mu \mathrm{l}$; lanes 1, 2), anti-140,000 $(4 \mu \mathrm{l}$; lanes 3,4$)$, anti-180,000 (4 $\mu \mathrm{l}$; lanes 5, 6), and anti-N-CAM-IgG (40 $\mu \mathrm{g}$; lanes 7,8$)$. The immunoprecipitates were dissolved in sampler buffer, boiled for $10 \mathrm{~min}$, and resolved by SDS-PAGE. Gels were dried and fixed for autoradiography on Kodak X-Omat film at $\sim 70^{\circ} \mathrm{C}$.
"01" antibody. Nearly all of the "04"-positive cells were positive for either anti-N-CAM or anti-OL-CAM (Table 2, Fig. 7). More than $99 \%$ of the " 01 "-positive cells were positive for N-CAM, and more than $80 \%$ of the "01" cells were positive for anti-OL-CAM (Fig. 7 and Table 2).

\section{$\mathrm{Ca}^{2+}$ dependency of $\mathrm{OL}$ aggregation}

$\mathrm{OL}$ were assayed for aggregation in the presence and absence of $\mathrm{Ca}^{2+}$. As is shown in Table 3, the aggregation of OL is dependent on the presence of $\mathrm{Ca}^{2+}$. This is in contrast to neuronal aggregation brought about by N-CAM (Edelman et al., 1983).

\section{Discussion}

Our earlier studies have indicated the presence of cell adhesion molecules in oligodendrocytes (Bhat and Silberberg, 1985). The glycoproteins responsible for $\mathrm{Ca}^{2+}$-dependent $\mathrm{OL}$ aggregation were purified from rat brain membranes by using detergent extraction, lentil-lectin affinity chromatography, and preparative SDS-PAGE. Three glycoproteins $(120,000,140,000$, and $180,000)$ had OL-CAM activity. Only the 120,000 protein of myelin and cultured OL had OL-CAM activity, which suggests that the 120,000 glycoprotein is responsible for OL aggregation. Preliminary studies indicated some similarities between N-CAM and OL-CAM. Therefore, OL-CAM was compared with N-CAM.

Table 2. Percentage of $04+$ or $01+$ cells that are positive for $\mathrm{N}-\mathrm{CAM}$ or OL-CAM $4 \mathrm{~d}$ after OL isolation

\begin{tabular}{lc} 
Antisera & Positive cells $(\%)$ \\
\hline $04 / \mathrm{N}-\mathrm{CAM}$ & 100 \\
$01 / \mathrm{N}-\mathrm{CAM}$ & 99 \\
$04 / 120$ & 98 \\
$01 / 120$ & 92 \\
$04 / 140$ & 97 \\
$01 / 140$ & 80 \\
$04 / 180$ & 97 \\
$01 / 180$ & 82
\end{tabular}

After isolation, OL were plated on glass coverslips. Four days after, cells were stained using various antisera. After immunostaining, labeled cells were counted using an epifluorescence microscope Carl Zeiss with a $63 \times$ objective lens. Positive cells in 10 fields were counted and the percentage of $04+/ \mathrm{N}-\mathrm{CAM}+$ or OL $\mathrm{CAM}+$, and $0 \mathrm{I}+/ \mathrm{N}-\mathrm{CAM}+$ or $\mathrm{OL}-\mathrm{CAM}+$ were calculated. Values are means from 4 separate experiments.
The results indicate that OL-CAM is closely related to one of the $(120,000)$ N-CAM family of glycoproteins.

Treatment of OL membranes with $N$-glycanase, which hydrolyzes $\mathrm{N}$-asparagine-linked oligosaccharides from glycoproteins, gave a 110,000 protein (Fig. 5). This is in agreement with the primary translation products D2-CAM mRNAs, one of which has an apparent $M_{\mathrm{r}}$ of 112,000 (Hansen et al., 1985).

$\mathrm{N}-\mathrm{CAM} / \mathrm{D} 2-\mathrm{CAM}$ is expressed in multiple forms that differ in their carbohydrate composition (Edelman et al., 1983; Goridis et al., 1983) and in the size of cytoplasmic domains (Gennerini et al., 1984), but are thought to be otherwise identical (Gennerini et al., 1984; Hoffman et al., 1982). Each of these molecular-weight classes may consist of several closely similar, but distinct, polypeptides. This possibility gains some support from the finding that N-CAMs from different brain regions can be distinguished serologically (Chuong and Edelman, 1984) and that each of these polypeptides may be derived from individual mRNAs (Hansen et al., 1985). In postembryonic brain, the 3 dominant forms of these molecules have relative $M_{\mathrm{r}} \mathrm{s}$ of 120,000 , 140,000, and 180,000 (Edelman and Choung, 1982; Hirn et al., 1981; Rasmussen et al., 1982). Glial cells reportedly do not express N-CAM/D2-CAM in vitro (Grumet et al., 1983, 1984; Hirn et al., 1981). However, recently Noble et al. (1985) and Keilhauer et al. (1985) have shown that all classes of macroglia express N-CAM/D2-CAM-like polypeptides in vitro. In addition to neurons, the presence of N-CAM in glial cells in vivo has been reported (Silver and Rutishauser, 1984).

With these studies as background, we compared N-CAM with OL-CAM. Three types of assays were used to compare OLCAM with N-CAM: (1) Western-blot analysis, in which antibodies react with the denatured protein; (2) immunoprecipita-

Table 3. Effect of $\mathrm{Ca}^{2+}$ on $\mathrm{OL}$ aggregation

\begin{tabular}{|c|c|}
\hline Additions & $\begin{array}{l}\text { Cells aggregated } \\
\text { at } 30 \mathrm{~min}(\%)\end{array}$ \\
\hline (a) EDTA & $48 \pm 4$ \\
\hline (b) $\quad$ EDTA $+\mathrm{Ca}^{2+}$ & $88 \pm 1$ \\
\hline
\end{tabular}

OL were isolated from 10-d-old primary mixed cultures of fetal rat brain. Cells were washed 2 times with $\mathrm{Ca}^{2+}-\mathrm{Mg}^{2+}$ free Hanks' buffer and incubated in Hanks' balanced salt solution containing $20 \mu \mathrm{g}$ DNase/ml, $1 \%$ fetal bovine serum, and $10 \mathrm{~mm}$ HEPES. (a) $1 \mathrm{~mm}$ EDTA and (b) $1 \mathrm{~mm}$ EDTA and $2 \mathrm{~mm} \mathrm{CaCl}_{2}$ were added to incubation medium before assaying for aggregation. Values are mean $\pm \mathrm{SD}$ from 4 experiments. 


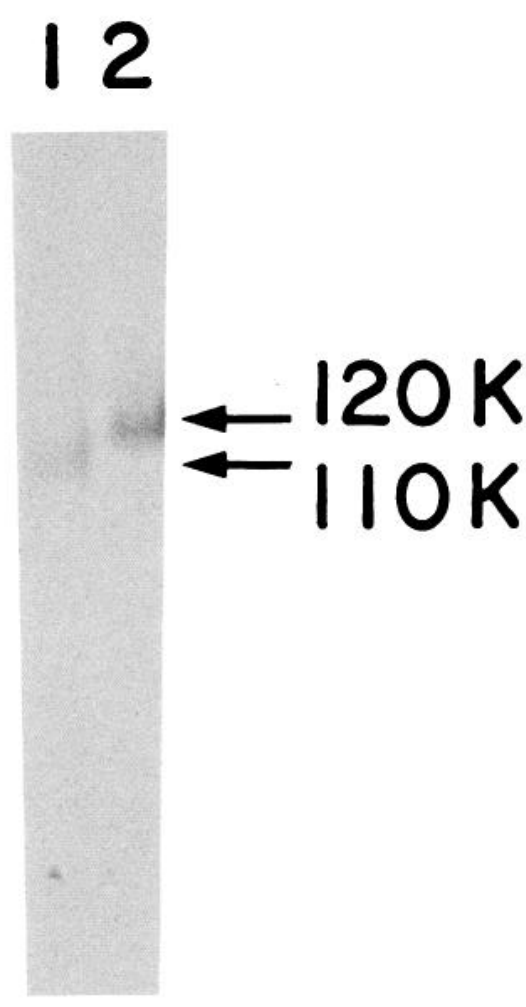

Figure 5. N-Glycanase cleavage of OL-CAM. Western-blot analysis of $N$-glycanase-treated OL membranes using anti-120,000 (1:3000 dilution). See Materials and Methods for detailed procedure. 1, N-glycanase-treated; 2 , control.

tion analysis, in which antibodies react with the native protein; and (3) immunofluorescence staining of cultured cells, in which antibodies react with accessible surface molecules. Western-blot analysis of NP40 extract of rat brain membranes and purified OL-CAM from rat brain showed identical patterns with antiN-CAM- and anti-OL-conditioned medium, and anti-120,000, anti-140,000, or anti-180,000 polypeptides. Immunoprecipitation using anti-N-CAM or anti-OL-CAM showed identical bands. Immunofluorescence analysis of the cultured OL also gave comparable results. These results suggest that N-CAM and OL-CAM are identical or related proteins. However, there is one major difference: OL-CAM requires $\mathrm{Ca}^{2+}$ for $\mathrm{OL}$ aggregation, while N-CAM does not require $\mathrm{Ca}^{2+}$ for neuronal aggregation.

Intercellular adhesion might occur via 2 distinct mechanisms, distinguished by in vitro aggregation assay: $\mathrm{Ca}^{2+}$-dependent and -independent (see review by Damsky et al., 1984). Takeichi et al. (1981) have observed $\mathrm{Ca}^{2+}$-dependent and -independent aggregation with a multipotent EC cell line, AT805, and with nullipotent F9EC cells. Thomas and Steinberg (1981) demonstrated the existence of $\mathrm{Ca}^{2+}$-dependent and -independent adhesion mechanisms in neural retinal cells. The studies done on the involvement of $\mathrm{Ca}^{2+}$ in N-CAM used chicken N-CAMs (Brackenbury et al., 1981). It is believed that rodent N-CAM also exhibits $\mathrm{Ca}^{2+}$-independent adhesion mechanisms. Moreover, adult chicken N-CAM has very little 120,000 protein. Therefore, it is possible that N-CAM may exhibit both $\mathrm{Ca}^{2+}$ dependent and -independent adhesion mechanisms. Also, it is possible that N-CAMs in different cell types may exhibit different requirements for $\mathrm{Ca}^{2+}$. Further studies are needed to substantiate this hypothesis.

The following findings suggest that the aggregation of $\mathrm{OL}$ is brought about by the 120,000 protein of the N-CAM family:

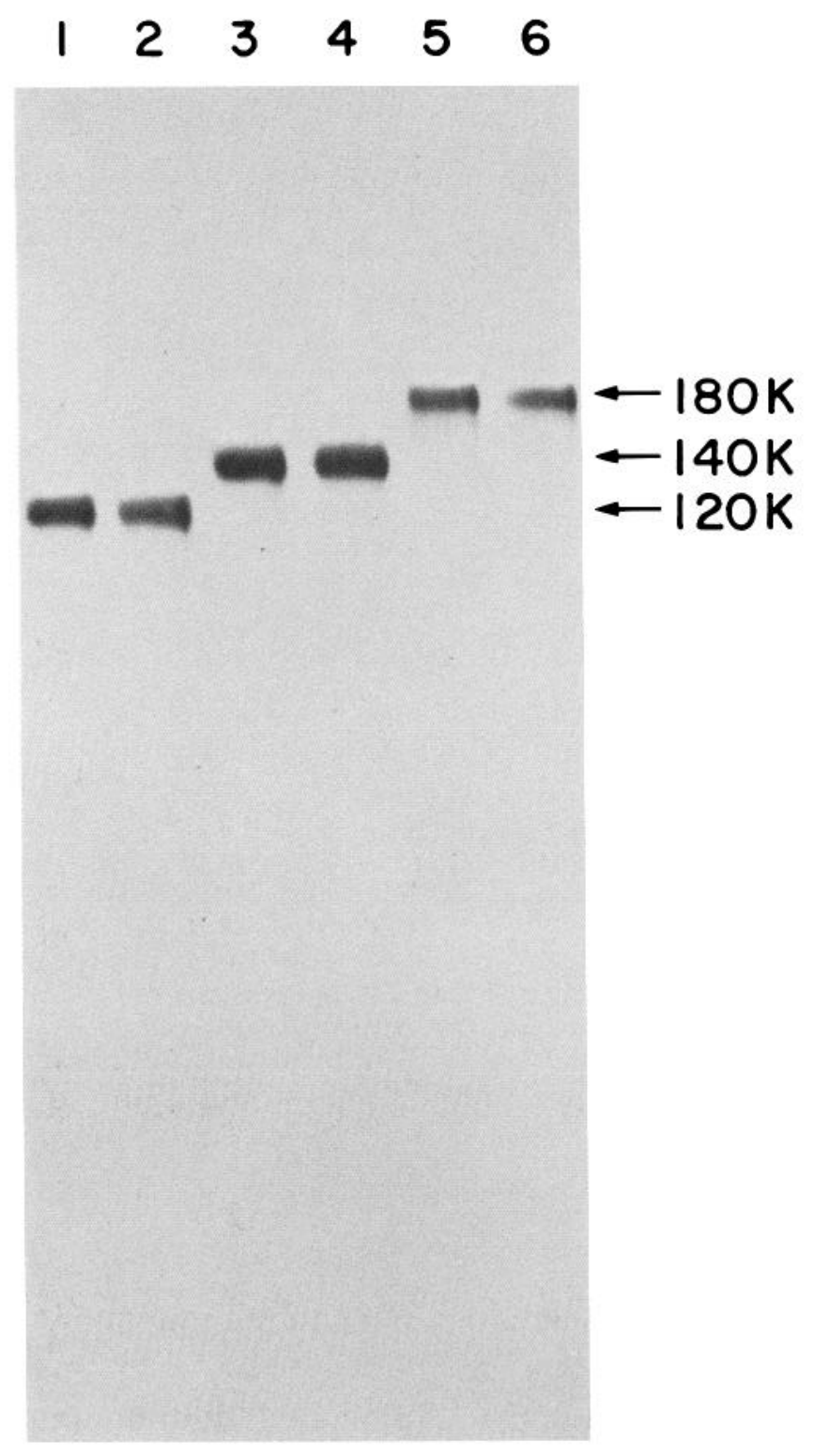

Figure 6. Western-blot analysis of OL-CAM using anti-N-CAM. Lanes $1,2, M_{\mathrm{r}}=120,000(5 \mu \mathrm{g}) ;$ lanes 3, 4, 140,000 (8 $\left.\mu \mathrm{g}\right) ;$ lanes 5, 6, 180,000 $(5 \mu \mathrm{g})$. Proteins in the nitrocellulose paper were stained by using antiN-CAM-IgG $(0.05 \mathrm{mg} / \mathrm{ml})$ and HRP-IgG (1:3000 dilution).

(1) 120,000 has the highest OL-CAM activity (Table 1); (2) Western-blot analysis and immunoprecipitation of iodinated OL membranes showed only 120,000 protein (Figs. 3 and 4); (3) highly purified myelin membranes also showed only 120,000 protein (Fig. 3); (4) Keilhauer et al. (1985) have shown that cultured neurons do not express 120,000, and pulse-chase studies, in cultured rat neuronal cells, of D2-CAMs showed no 120,000 polypeptides (Lyles et al., 1984); (5) the studies of Chuong and Edelman (1984) showed that neuron-rich regions of mouse brain, e.g., hippocampus and olfactory bulb, had very little protein of $120,000 M_{\mathrm{r}}$, while, conversely, OL-rich regions such as cerebellum, cerebral cortex, and spinal cord had high levels of 120,000; (6) in explant cultures, 180,000, 140,000, and 120,000 are synthesized de novo, and not by modification of the existing high-molecular-weight N-CAMs (Friedlander et al., 1985).

To summarize: We have isolated OL-CAM, which is closely related to one of the N-CAM family of proteins. It will be of 

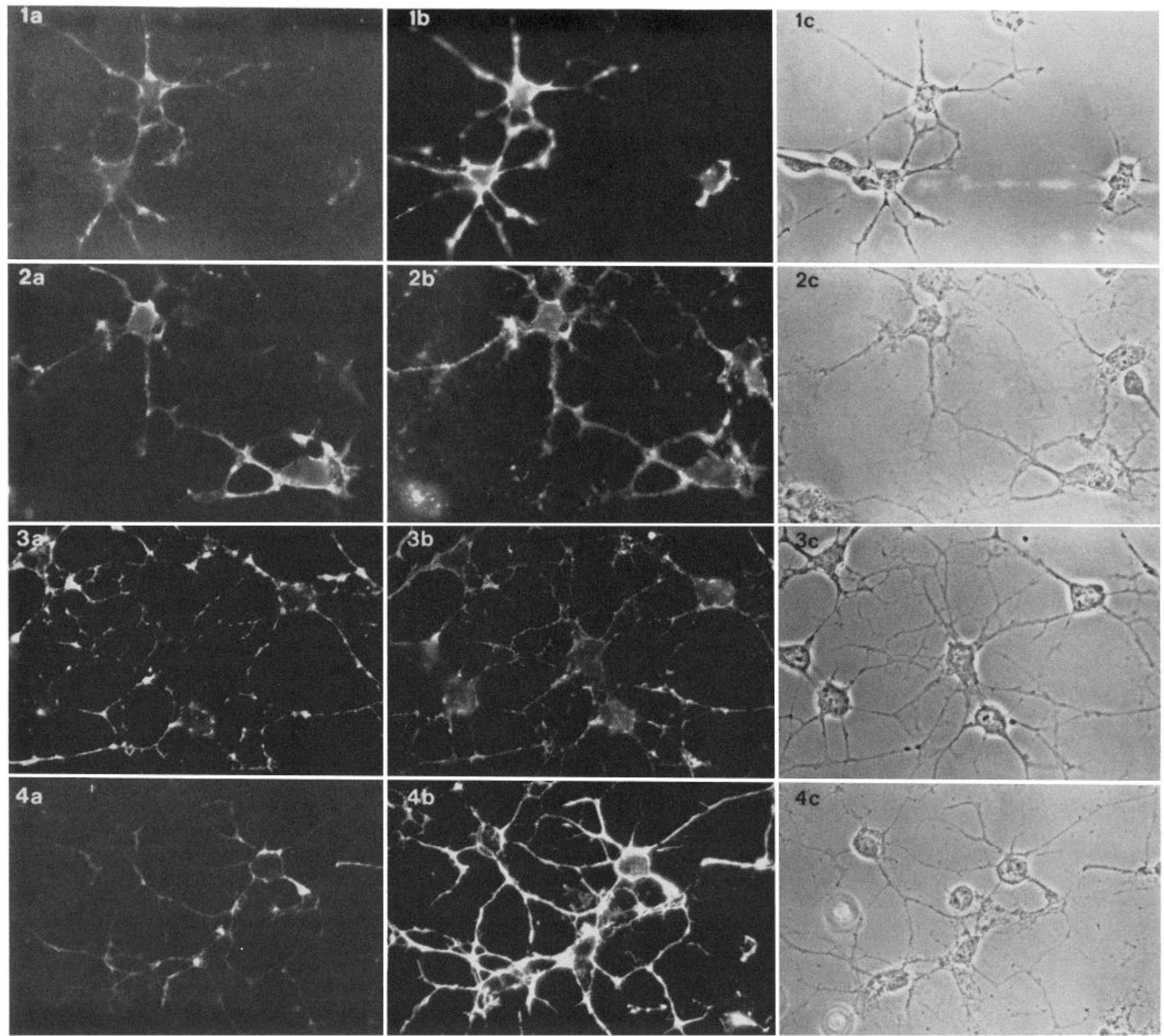

Figure 7. Immunofluorescence staining of cultured OL by anti-N-CAM and anti-OL-CAM. OL were cultured on glass coverslips after isolation. Four days after isolation and culture, the cells were stained by anti-N-CAM-IgG $(0.05 \mathrm{mg} / \mathrm{ml})$, anti-120,000 (1:50), "04" (1:100) and " 01 " (1:100). Rhodamine-conjugated goat anti-rabbit $\operatorname{IgG}(1: 100)$ and fluorescein-conjugated goat anti-mouse $\operatorname{IgG}(1: 50)$ were used as second antibodies. $1 a$ and $3 a$, " 04 "; $2 a$ and $4 a$, " 01 "; $I b$ and $2 b$, anti-N-CAM; $3 b$ and $4 b$, anti-120,000. $a$, Fluorescein ( $428 \times)$; $b$, rhodamine (428 $\times)$; and $c$, phase contrast $(428 \times)$.

interest to see whether OL-CAM serves as a means of communication between $\mathrm{OL}$ and neurons, and $\mathrm{OL}$ and astrocytes.

\section{References}

Bhat, S., and D. H. Silberberg (1985) Oligodendrocytes have cell adhesion molecules. Dev. Brain Res. 19: 139-145.

Bolton, A. E., and W. M. Hunter (1973) The labeling of proteins to high specific radioactivities by conjugation to a ${ }^{125}$ I-containing acylating agent. Biochem. J. 133: 529-539.

Brackenbury, R., U. Rutishauser, and G. M. Edelman (1981) Distinct calcium-independent and calcium-dependent adhesion systems of chicken embryo cells. Proc. Natl. Acad. Sci. USA 78: 387-391.

Chuong, C.-M., and G. M. Edelman (1984) Alterations in neural cell adhesion molecules during development of different regions of the nervous system. J. Neurosci. 4: 2354-2368.
Damsky, C. H., K. A. Knudsen, and C. A. Buck (1984) Integral membrane glycoproteins in cell-cell and cell-substratum adhesion. In The Biology of Glycoproteins, R. J. Ivatt, ed., pp. 1-64, Plenum, New York.

Dobberstein, B., H. Garoff, and C. Warren (1979) Cell-free synthesis and membrane insertion of mouse $\mathrm{H}-2 \mathrm{D}$ histocompatibility antigen and $\gamma_{2}$-microglobulin. Cell 17: 759-769.

Edelman, G. M. (1984) Cell surface modulation and marker multiplicity in neural patterning. Trends Neurosci. 7: 78-84.

Edelman, G. M., and A. Choung (1982) Embryonic to adult conversion of neural cell adhesion molecules in normal and staggerer mice. Proc. Natl. Acad. Sci. USA 79: 7035-7038.

Edelman, G. M., S. Hoffman, C.-M. Chuong, J. P. Thiery, R. Brackenbury, W. J. Gallin, M. Grumet, M. E. Greenberg, J. J. Hemperly, C. Cohen, and B. A. Cunningham (1983) Structure and modulation of neural cell adhesion molecules in early and late embryogenesis. Cold Spring Harbor Symp. Quant. Biol. 48: 515-526. 
Elder, J. H., and S. Alexander (1982) Endo- $\beta-N$-acetylglucosaminidase F: Endoglycosidase from flavobacterium meningosepticum that cleaves both high mannose and complex glycoproteins. Proc. Natl. Acad. Sci. USA 79: 4540-4544.

Friedlander, D. R., R. Brackenbury, and G. M. Edelman (1985) Conversion of embryonic form to adult forms of N-CAM in vitro: Results from de novo synthesis of adult forms. J. Cell Biol. 101: 412-419.

Gennerini, G., G. Rougon, H. Deagostim-Bazin, M. Hirn, and C. Goridis (1984) Studies on the transmembrane disposition of the neural cell adhesion molecule N-CAM. Eur. J. Biochem. 142: 57-64.

Goridis, C., H. Deagostini-Bazin, M. Hirn, M.-R. Hirsch, G. Rougon, R. Sadoul, O. K. Langlcy, C. Gombos, and J. Finne (1983) Neural surface antigens during nervous system development. Cold Spring Harbor Symp. Quant. Biol. 48: 527-537.

Grumet, M., J. Rutishauser, and G. M. Edelman (1983) Neuron-glia adhesion is inhibited by antibodies to neural determinants. Science 222: 60-62.

Grumet, M., S. Hoffman, and G. M. Edelman (1984) Two antigenically related neural CAMs of different specificities mediate neuron-neuron and neuron glia adhesion. Proc. Natl. Acad. Sci. USA 81: 267-271.

Hansen, O. C., O. Nybroe, and E. Bock (1985) Cell-free synthesis of the D2-cell adhesion molecules: Evidence for three primary translation products. J. Neurochem. 44: 712-717.

Hirn, J., M. Pierres, J. Deagostini-Bazin, M. Hirsch, and C. Goridis (1981) Monoclonal antibody against cell surface glycoprotein of neurons. Brain Res. 214: 433-439.

Hirn, M., M. D. Ghandour, J. Deagostini-Bazin, and C. Goridis (1983) Molecular heterogeneity and structural evolution during cerebellar ontogeny detected by monoclonal antibody of the mouse cell surface antigen BSP-2. Brain Res. 265: 87-100.

Hoffman, S., B. C. Sorkin, P. C. White, R. Brackenbury, R. Mailhammer, U. Rutishauser, B. A. Cunningham, and G. M. Edelman (1982) Chemical characterization of neural cell adhesion molecules purified from embryonic brain membranes. J. Biol. Chem. 257: 7720-7729.

Jorgensen, O. S., A. Delouvée, J. P. Thiery, and G. M. Edelman (1980) The nervous system specific protein D2 is involved in adhesion among neuritis from cultured rat ganglia. FEBS Lett. 111: 39-42.

Keilhauer, G., A. Faissner, and M. Schachner (1985) Differential inhibition of neuron-neuron, neuron-astrocyte and astrocyte-astrocyte adhesion by L1, L2 and N-CAM antibodies. Naturc 316: 728-730.

Laemmli, U. K. (1970) Cleavage of structural proteins during the assembly of the head of bacteriophage T4. Nature 227: 680-685.

Lowry, O. H., N. J. Rosebrough, A. L. Farr, and R. J. Randall (1951)
Protein measurement with the folin phenol reagent. J. Biol. Chem. 193: 265-275.

Lyles, J. M., B. Norrild, and E. Bock (1984) Biosynthesis of the D2 cell adhesion molecule: Pulse-chase studies in cultured fetal rat neuronal cells. J. Cell Biol. 98: 2077-2081.

Noble, M., M. Albrechtsen, C. Moller, J. Lyles, E. Bock, C. Goridis, M. Watanabe, and U. Rutishauser (1985) Glial cells express N-CAM D2-CAM-like polypeptides in vitro. Nature 316: 725-728.

Norton, W. T., and S. E. Poduslo (1973) Myelination in rat brain: Method of myelin isolation. J. Neurochem. 21: 749-757.

Raff, M., R. Mirsky, K. Fields, R. Lisak, S. Dorfman, D. H. Silberberg, N. Gregson, S. Leibowitz, and M. Kennedy (1978) Galactocerebroside is a specific cell-surface marker tor oligodendrocytes in culture. Nature 276: 813-816.

Rasmussen, S., J. Ramlan, N. H. Axelsen, and E. Bock (1982) Purification of the synaptic membrane glycoprotein D2 from rat brain. Scand. J. Immunol. 15: 179-185.

Rutishauser, U. (1983) Molecular and biological properties of a neural cell adhesion molecule. Cold Spring Harbor Symp. Quant. Biol. 48: 501-514.

Silver, J., and U. Rutishauser (1984) Guidance of optic axons in vivo by a preformed adhesion pathway on neuroepithelial end feet. Dev. Biol. 106: 485-499.

Singh, H., and S. E. Pfeiffer (1985) Myelin-associated galactolipids in primary cultures from dissociated fetal rat brain: Biosynthesis, accumulation, and cell surface expression. J. Neurochem. 45: 13711381.

Sommer, I., and M. Schachner (1981) Monoclonal antibodies (01 and 04) to oligodendrocyte cell surfaces: An immunocytological study in the central nervous system. J. Neurol. Sci. 47: 135-144.

Sommer, I., and M. Schachner (1982) Cells that are 04 antigen-positive and $\mathrm{OL}$ antigen-negative differentiate into OL-positive oligodendrocytes. Neurosci. Lett. 29: 183-188.

Takeichi, M., J. Atsumi, K. U. Yoshida, and J. S. Okada (1981) Selective adhesion of embryonal carcinoma cells and differentiated cells by $\mathrm{Ca}^{++}$-dependent sites. Dev. Biol. 87: 340-350.

Thomas, W. A., and M. S. Steinberg (1981) Two distinct adhesion mechanisms in embryonic neural retina cells. Dev. Biol. 81: 106114.

Towbin, II., T. Staehlin, and J. Gordon (1979) Electrophoretic transfer of proteins from polyacrylamide gels to nitrocellulose sheets: Procedure and some applications. Proc. Natl. Acad. Sci. USA 76: 43504354 . 